\title{
Biodiesel Synthesis by Ethanolysis of Hura crepitans Seed Oil Unfit for Consumption in Benin
}

\author{
Assou Sidohounde ${ }^{1}$, Guevara Nonviho ${ }^{1}$, Fifa Theomaine Diane Bothon ${ }^{1}$, Papin Sourou Montcho ${ }^{1}$, \\ Cokou Pascal Agbangnan Dossa ${ }^{1}$, Leopold Tchiakpe ${ }^{2}$, Dominique Codjo Koko Sohounhloue ${ }^{1, *}$ \\ ${ }^{1}$ Department of Chemical Engineering-Processes, Polytechnic School of Abomey-Calavi, University of Abomey-Calavi, Abomey-Calavi, \\ Benin \\ ${ }^{2}$ Bio-Pharmaceutical Engineering Department, Pharmacy Faculty, University of Aix-Marseille, Marseille, France
}

\section{Email address:}

Sidohoundeassou1984@gmail.com (A. Sidohounde), gnonviho@gmail.com (G. Nonviho), botheo200108@gmail.com (F. T. D. Bothon), montchopapin@gmail.com (P. S. Montcho),cokou2010@gmail.com (C. P. A. Dossa), leopold.tchiakpe@univ-amu.fr(L. Tchiakpe), csohoun@gmail.com (D. C. K. Sohounhloue), ksohoun@bj.refer.org (D. C. K. Sohounhloue)

${ }^{*}$ Corresponding author

\section{To cite this article:}

Assou Sidohounde, Guevara Nonviho, Fifa Theomaine Diane Bothon, Papin Sourou Montcho, Cokou Pascal Agbangnan Dossa, Leopold Tchiakpe, Dominique Codjo Koko Sohounhloue. Biodiesel Synthesis by Ethanolysis of Hura crepitans Seed Oil Unfit for Consumption in Benin. American Journal of Physical Chemistry. Vol. 8, No. 3, 2019, pp. 50-57. doi: 10.11648/j.ajpc.20190803.11

Received: September 11, 2019; Accepted: October 7, 2019; Published: October 20, 2019

\begin{abstract}
To reduce fossil fuel dependence and greenhouse gases, biomass energy is in high demand. Hura crepitans (HC) is a widely distributed plant species in Benin. But its seed oils are reputed to be purgative and unfit for consumption. So, we collected the seeds of HC in Agame (South of Benin). They were extracted and the seed oils have been converted into biodiesel. First, the quality indices (acid, peroxide, iodine and saponification) were determined. Then, elementary physicochemical parameters and fuel properties of the extracted oil have been highlighted according to standardised methods. Transesterification parameters of the seed oils (alcohol/oil and catalyst/oil ratios, temperature and yield) were also studied. The fatty acids of vegetable oil and the characteristics of its obtained biodiesel were finally identified. It appears that HC seeds have a lipid potential of $52.54 \%$. Its oil is unsaturated and dominated by linoleic acid $(54.13 \%)$. The yield of the transesterification reaction is $81.47 \%$. The fuel parameters of the obtained biodiesel are: acidity $(0.41 \%)$; density at $26^{\circ} \mathrm{C}$ (0.887); cetane number (54.44) compared to those of $\mathrm{HC}$ seed oils: acidity $(4.81 \%)$, density at $26^{\circ} \mathrm{C}(0.929)$ and cetane number (44.53). The biodiesel obtained by transesterification with potash has much better parameters that comply with biodiesel standards. These results suggest that biodiesel of HC could be proposed to power Diesel engines without a preheating system.
\end{abstract}

Keywords: Hura Crepitans, Transesterification, Biodiesel, Fuel Parameters

\section{Introduction}

Throughout the world, the industrial revolution has given a prominent place to energies such as nuclear, fossil, natural gas and coal [1]. In order to anticipate the decline of these energies and reduce greenhouse gases, the exploration of renewable energies, particularly biodiesel, has been launched. Despite of thehigh cost of their production, food and arable land competitions, biofuels remain a credible alternative source because they are renewable [2-4]. Indeed, with their biodegradability and low toxicity to animal species and micro-organisms, they present little or no environmental risk unlike fossil oil [5]. A wise choice of unused or poorly consumed forest oil resources is necessary to limit controversy. However, whatever their origin, the combustion of crude vegetable oils produces oxygenated hydrocarbons at low temperatures, which leads to the thermal braking of diesel engines. They undergo physical and chemical changes in the combustion chambers, especially in engines, with the formation of gums, triglycerides and a large amount of carbon, etc. on metal parts, which reduces their volatility [6, 7]. So, it is necessary to proceed its transformation into biodiesel. Several conversion methods such as: transesterification, interesterification, microemulsification 
and pyrolysis are possible [8-10]. Of all these processes, transesterification is the most widely used because of its simplicity, the best yields it offers and the quality of the biodiesel obtained [11]. This reaction is influenced by several factors whose control is essential to optimize performance. These factors include: alcohol/oil and catalyst/oil ratios; reaction temperature; water content of vegetable oil and alcohol; reaction time; amount of free fatty acids; and agitation of the reaction medium. To produce biodiesel that is $100 \%$ renewable in origin, vegetable oil ethyl esters are preferred. Indeed, it can be obtained by using bioethanol from sugar biomass or lignocellulosic biomass and are less toxic than methanol $[9,10,12]$. Benin is full of oilseed raw materials with little or no value due to the lack of chemical and technical knowledge. Present study aims to produce biodiesel from unconventional vegetable oil of Hura crepitans harvested in Benin.

\section{Material and Methods}

\subsection{Plant Material}

The plant material investigated consists of Hura crepitans seeds called bombardier in French. In Beninese vernacular languages, the tree is known as: "Wuntin" in Fongbe and "kekefotin" in Goungbe. The seeds are collected at "Agame" (southern Benin) and shelled. The almonds are sun dried, crushed and the flour obtained is sieved with a sieve of 0.8 or $1 \mu \mathrm{m}$ diameter and stored at $40^{\circ} \mathrm{C}$ in the oven until the end of the extraction.

\subsection{Extraction of Vegetable Oil}

The extraction of vegetable oil was carried out under atmospheric pressure at $69 \pm 1{ }^{\circ} \mathrm{C}$ for 6 hours with Soxhlet using hexane according to the standard ISO 659 method (1989).

\subsection{Determination of Physicochemical Properties of Seed Oil}

The water content, density and viscosity of the seeds oils were determined according to standard methods (DIN EN ISO 12937, NF T 60-214, NF T 60-214, and NF ISO 3104).

The acidity, peroxide and saponification value (SV) are determined respectively according to French standards $\mathrm{T}$ 60204; T 60-220 and T 60-206. The iodine value was evaluated by the Winkler method.

The lower calorific value (1) of the crude oil in $\mathrm{kJ} / \mathrm{kg}$ was calculated by the approximate formula [13] using the previously determined iodine value (IV) and saponification value $(\mathrm{SV})$.

$$
\mathrm{LCV}=47645-4.187 \mathrm{IV}-38.31 \mathrm{SV}
$$

The cetane number (2) was calculated by the Klopfenstein formula [13]. This formula uses the value of the saponification index of the extracted vegetable oils.

$$
\mathrm{CN}=46.3+\frac{5458}{\mathrm{SV}}-0.225 \mathrm{IV}
$$

The refractive index (3) is determined using the Perkins mathematical formula reported by Babatunde and Bello [14].

$$
\mathrm{RI}=1.45765+0.0001164 \mathrm{IV}
$$

\subsection{Fatty Acids of Seed Oil and Ethyl Ester of Biodiesel Determinations}

Fatty acids profile was determined through the fatty acid methyl esters (FAMEs). Thus, FAMEs were obtained by using Ackman method [15] as previously reported by Lepage and Roy [16] and Masood et al. [17].

FAMEs of seed oil and ethyl esters of biodiesel were both analyzed by coupling gas chromatography (Thermo Fischer Scientific Ultra Brand) with mass spectrometry (GC / MS). Chromatographic analysis was performed on Trace GC Ultra equipped with an ASI 3000 auto sampler and with Polaris Q spectral mass detector, all from Thermo Fischer Scientific Ultra Brand. The coupling and the automatic control of the devices have been done by the software EXCALIBUR 2.0 Thermo Fisher. The Split/splitless injector was set at $250^{\circ} \mathrm{C}$ and the ion source temperature set at $250^{\circ} \mathrm{C}$. Ultrapure Helium Alpha-gas 2 was the gas carrier set at $1 \mathrm{ml} / \mathrm{min}$ constant flow with automatically adjusted pressure. Injections were on split mode. GC was fitted with a fused silica capillary column (DB-FFAP) $30 \mathrm{~m} \times 0.25 \mathrm{~mm}$ inner diameter (ID) x $0.25 \mu \mathrm{m}$ film thickness (J \& W Scientific, Agilent Technologies). Initial oven temperature was $130^{\circ} \mathrm{C}$. The program temperature was as follows: equilibration time: $0.5 \mathrm{~min}$; linear increase to $178^{\circ} \mathrm{C}$ at $4^{\circ} \mathrm{C} / \mathrm{min}$, followed by linear increase to $210^{\circ} \mathrm{C}$ at $1^{\circ} \mathrm{C} / \mathrm{min}$, followed by an increase to $245^{\circ} \mathrm{C}$ at $40^{\circ} \mathrm{C} / \mathrm{min}$ and final $13 \mathrm{~min}$ hold. The duration of the analysis was $60 \mathrm{~min}$. The injected volume was $1 \mu \mathrm{L}$ and the injected amount $10 \mu \mathrm{g} / \mathrm{mL}$. Positive ionization of the FAMEs was performed by electronic impact (EI), with $70 \mathrm{eV}$ energy and full scan detection mod. Mass spectra range was $50-650 \mathrm{~m} / \mathrm{z}$; scan $0.58 \mathrm{sec}$.

Precise identification of the analytes was achieved by their relative retention times and mass spectra on the spectral mass database NIST libraries for fatty acid composition. External fatty acid standards were the 28 FAMEs compounds NUCHEK-PREP inc Elysian USA, (GLC reference standard 462) and the Supelco 37 component FAMEs mix (CRM 47885).

\subsection{Transesterification}

Transesterification reaction was done by following the diagram of figure 1. Acidity greater than $1 \%$ has been evaluatedin advance for crude vegetable oil. This required neutralization of the vegetable oil with an ethanolic solution of potassium hydroxide before preheating. Under stirring, an ethanolic solution of $1.1 \%$ potassium hydroxide in an ethanol/oil ratio of 6 was added. After 1 hour of agitation of the mixture at $45^{\circ} \mathrm{C}$, a settling time of 16 hours or more was followed. A separation of the raw biodiesel from the alcoholrich aqueous phase was performed. After washing with warm distilled water, the product is subjected to one hour of distillation at $100^{\circ} \mathrm{C}$. Thin layer chromatography of the 
product was then performed using the Ichihara and Fukubayashi [18] method to verify the purity of the biodiesel.
The process was stopped after a good yield of ethyl esters had been obtained and resumed if not.

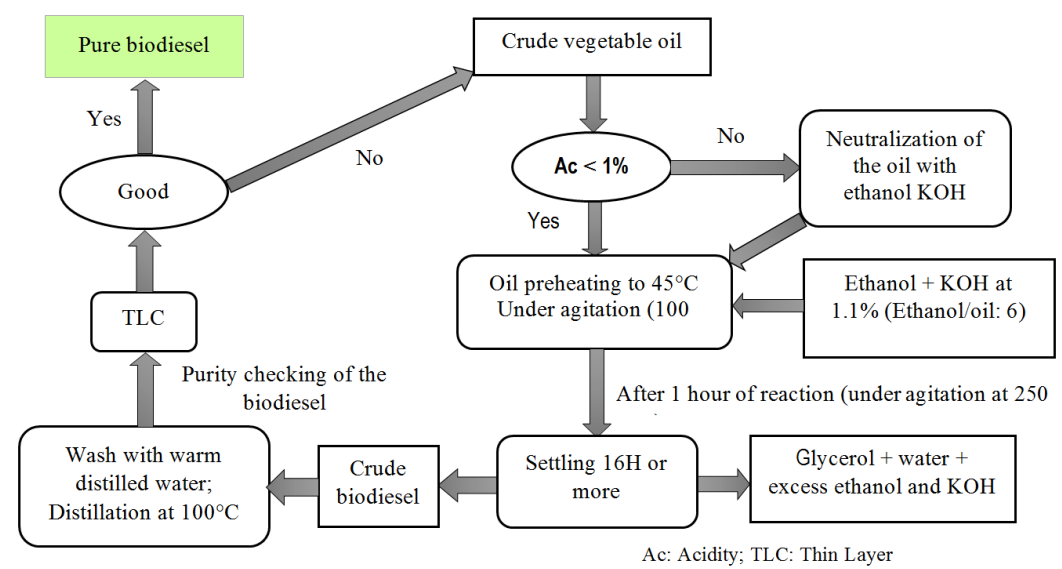

Figure 1. Transesterification process.

\section{Results and Discussion}

\subsection{Physical and Chemical Characteristics of Hura Crepitans Vegetable Oil}

Physical and chemical characteristics of Hura crepitans $(H C)$ are shown on Table 1 . The lipid potential of $H C$ seeds is $52.54 \%$. The acidity of vegetable oil above $1 \%$ requires its neutralization before its use in diesel engines [19]. The high peroxide value $\left(>10 \quad \mathrm{meqO}_{2} / \mathrm{kg}\right)$ indicates that vegetable oil has a high concentration of peroxide and hydroperoxide which are primary products of autoxidation. A use in food is therefore ruled out at this stage. This could be related to its exposure to air, light, heat or its composition in unsaturated fatty acids. This index makes it possible to predict future behaviour in terms of fat stability and to take conservation measures [20-22]. The high iodine index shows the unsaturated character. This parameter reflects the fluidity of vegetable oil [23]. This is confirmed by the fatty acid composition of vegetable oil which shows the predominance of unsaturated fatty acids (84.90\%), particularly linoleic acid $(54.13 \%)$ [23, 24]. These results are significantly different from those of Adewuyi et al. [13] and Owolabi et al. [25] who worked on the same species in Nigeria. This could depend on several parameters including the variety, climate, soil growing conditions and morphology of the matrices studied [26, 27]. Indeed, although the study conducted by Owolabiet al. [25] showed a much unsaturated oil, saturated fatty acids are also well represented $(34.12 \%)$.

Table 1. Physico-chemical characteristics, oil yield and fatty acids of Hura crepitans kernel

\begin{tabular}{llll}
\hline & Yield (\%) & HC & HC [28-30] \\
\cline { 2 - 4 } Quality indices & Fr.54 $\pm \mathbf{0 . 2 2}$ & $\mathbf{3 6 . 4 0 - 4 7 . 8 0}$ \\
& Pree fatty acids (\% Linoleic acid) & $4.81 \pm 0.14$ & $1.64-4.10$ \\
& Peroxide value $\left(\mathrm{meq} \mathrm{O}_{2} / \mathrm{kg}\right)$ & $28.02 \pm 0.38$ & $2.14-9.10$ \\
& Iodine value $\left(\mathrm{g} \mathrm{I}_{2} / 100 \mathrm{~g}\right)$ & $123.21 \pm 0.41$ & $122.08-149.10$ \\
& Saponification value $(\mathrm{mg} \mathrm{KOH} / \mathrm{g})$ & $210.29 \pm 1.27$ & $202.00-210.38$ \\
\hline
\end{tabular}

Table 1. Continued.

\begin{tabular}{|c|c|c|c|c|}
\hline \multirow{2}{*}{ Acides gras } & & $H C$ & $H C[15]$ & $H C[25]$ \\
\hline & & $(\%)$ & $(\%)$ & $(\%)$ \\
\hline \multirow{6}{*}{ Saturated fattyacids } & Tridecylic acid (C13:0) & $0.13 \pm 0.01$ & ND & ND \\
\hline & Palmitic acid (C16:0) & $9.14 \pm 0.08 \mathrm{c}$ & $12.20 \mathrm{~b}$ & $21.67 \mathrm{a}$ \\
\hline & Margaric acid (C17:0) & $0.02 \pm 0.01 \mathrm{~b}$ & ND & $0.31 \mathrm{a}$ \\
\hline & Stearic acid (C18:0) & $5.63 \pm 0.06 \mathrm{~b}$ & $5.10 \mathrm{~b}$ & $9.66 \mathrm{a}$ \\
\hline & Arachidic acid (C20:0) & $0.07 \pm 0.00 \mathrm{c}$ & $0.20 \mathrm{~b}$ & $2.48 \mathrm{a}$ \\
\hline & Tricosylic acid (C23:0) & $0.07 \pm 0.00$ & ND & ND \\
\hline \multirow[t]{2}{*}{ Total of saturated fatty acids } & & $15.06 \pm 00 \mathrm{c}$ & $17.50 \mathrm{~b}$ & $34.12 \mathrm{a}$ \\
\hline & Palmitoleic acid (C16:1, n-7) & $0.09 \pm 0.00 \mathrm{~b}$ & $0.10 \mathrm{~b}$ & $0.57 \mathrm{a}$ \\
\hline \multirow{5}{*}{ Unsaturated fattyacids } & Oleic acid $(\mathrm{C} 18: 1, \mathrm{n}-9)$ & $27.34 \pm 0.00 \mathrm{a}$ & $27.20 \mathrm{~b}$ & $26.91 \mathrm{c}$ \\
\hline & Linolelaïdic acid (C18:2) & $0.92 \pm 0.01$ & ND & ND \\
\hline & Linoleic acid $(\mathrm{C} 18: 2, n-9,12)$ & $54.13 \pm 0.04 a$ & $52.80 \mathrm{~b}$ & $36.61 \mathrm{c}$ \\
\hline & $\alpha$ - linolenic acid (C18:3) & $2.36 \pm 0.03 a$ & $1.80 \mathrm{~b}$ & $0.75 \mathrm{c}$ \\
\hline & Gondoic acid (C20:1) & $0.06 \pm 0.00$ & ND & ND \\
\hline Total of unsaturated fatty acid & & $84.90 \pm 0.00 \mathrm{a}$ & $81.90 \mathrm{~b}$ & $64.84 \mathrm{c}$ \\
\hline
\end{tabular}

HC: Hura crepitans; ND: No Detected. 
The data in a line followed by different letters are significantly different $(p<0.05)$. The values are averages of three repetitions \pm standard deviation.

\subsection{Some Fuel Characteristics of Hura Crepitans Vegetable Oil}

The comparative study of the fuel characteristics of $H C$ vegetable oil recorded in Table 2 shows fuel parameters that generally comply with DIN 51605 for pure fuel rapeseed oil [7] except for the determined acidity, which remains higher.
A neutralization of the vegetable oil is therefore necessary before its use in diesel engines to avoid corrosion of metal parts. But this has consequences for the operation of engines that will use it directly in cold conditions [7, 31]. Compared to the biodiesel standard EN 14214 from the same sources, the acidity is even higher $(4.81 \%)$ as well as the relative density $(0.929)$ at $26^{\circ} \mathrm{C}$. There is also a lower cetane number than that recommended by the biodiesel standard EN 14214. A conversion of vegetable oil into biodiesel is therefore necessary for diesel engines to improve their fuel parameters.

Table 2. Some fuel characteristics of Hura crepitans vegetable oil.

\begin{tabular}{|c|c|c|c|}
\hline \multirow{2}{*}{ Characteristics } & \multirow{2}{*}{$H C$} & \multirow{2}{*}{$\begin{array}{l}\text { Specification for vegetable rapeseed oil } \\
\text { DIN } 51605[7]\end{array}$} & \multirow{2}{*}{$\begin{array}{l}\text { Specification for biodiesel [31] } \\
\text { EN } 14214\end{array}$} \\
\hline & & & \\
\hline Moisture content $(\%)$ & $0.06 \pm 0.00 \mathrm{a}$ & $0.075 \mathrm{a}$ & Max: $0.05 \mathrm{a}$ \\
\hline Ethyl linolenate content (\%) & $2.36 \pm 0.03 b$ & - & Max: $12 \mathrm{a}$ \\
\hline Polyunsaturated ester content $(\mathrm{C}=\mathrm{C} \geq 4, \%)$ & $\mathrm{ND}$ & - & Max: 1 \\
\hline Acidity $(\%)$ & $4.81 \pm 0.14 \mathrm{a}$ & Max: $1.5 b$ & Max: $0.5 \mathrm{c}$ \\
\hline Density $\left(a ̀ ~ 26^{\circ} \mathrm{C}\right)$ & $0.929 \pm 0.001 \mathrm{a}$ & $0.90-0.93 a$ & $0.86-0.90 \mathrm{~b}(*)$ \\
\hline Cetane number & $44.53 \pm 0.06 \mathrm{~b}$ & Min: $35 \mathrm{c}$ & Min: $51 \mathrm{a}$ \\
\hline Refractive index & $1.472 \pm 0.001$ & - & ND \\
\hline
\end{tabular}

HC: Hura crepitans; ND: No Detected; Max: maximum limit; Min: minimum limit; (*): density at $20^{\circ} \mathrm{C}$.

The data in a line followed by different letters are significantly different $(p<0.05)$. The values are averages of three repetitions \pm standard deviation.

\subsection{Transesterification Reaction}

\subsubsection{Effect of the Molar Ratio Ethanol/Oil}

Figure 2 shows the influence of the ethanol/oil molar ratio on the conversion rate of $\mathrm{HC}$ vegetable oil. The reaction time has a positive impact on the reaction performance. Within the first $20 \mathrm{~min}$ for the 4:1 molar ratio and $50 \mathrm{~min}$ for two other ratios $(6: 1 ; 8: 1)$, the oil conversion rate increases rapidly before beginning its progressive evolution. The molar ratio of 8:1 slightly increases yield within the first $10 \mathrm{~min}$. This molar ratio has no major effect on the conversion rate of vegetable oils into biodiesel in general. Thus the molar ratio ethanol/oil of 6 is retained for the rest of the operations.

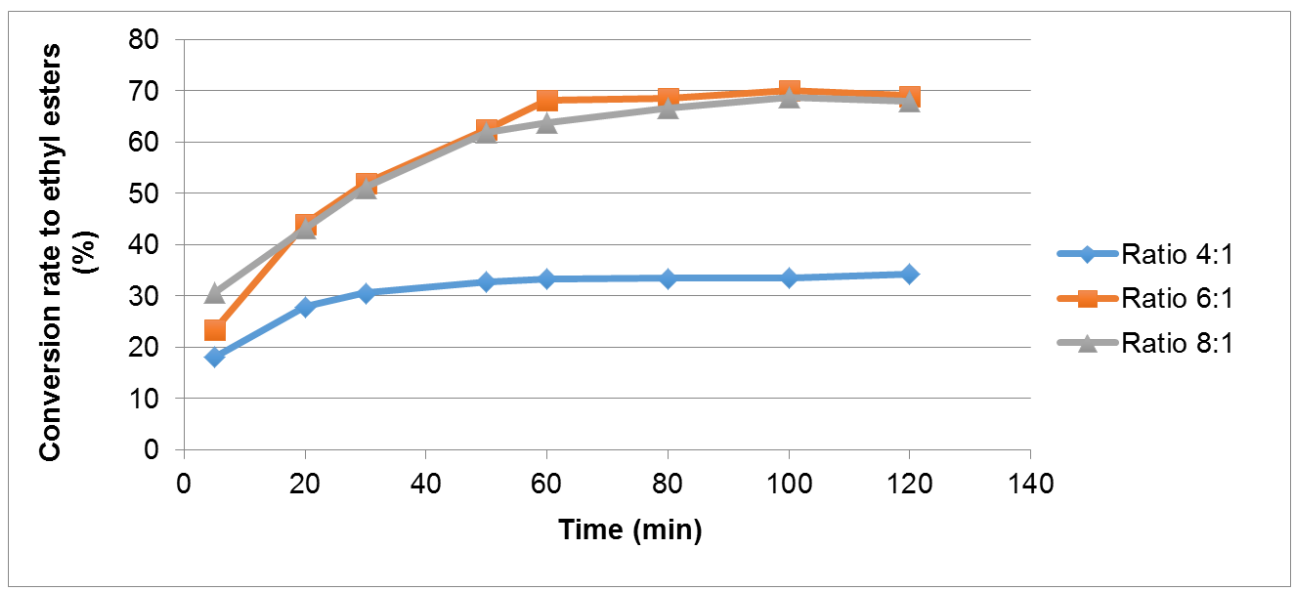

Figure 2. Evolution of the molar ratio on the conversion of vegetable oil from Hura crepitans to biodiesel (35 ${ }^{\circ} \mathrm{C}$; anhydrous ethanol; $\left.1 \% \mathrm{KOH} ; 250 \mathrm{rpm}\right)$.

\subsubsection{Effect of Temperature and Reaction Time on Transesterification}

Figure 3 shows the influence of temperature and reaction time on the conversion rate of $\mathrm{HC}$ vegetable oil. Within the first $5 \mathrm{~min}$, the conversion rate from vegetable oil to biodiesel is proportional to the temperature of the reaction. Beyond this time, a temperature above $45^{\circ} \mathrm{C}$ is not cost- effective. After $60 \mathrm{~min}$ of reaction, the temperature increase is without any major positive impact or on the contrary reduces the conversion efficiency. $45^{\circ} \mathrm{C}$ is therefore the most suitable temperature for converting $\mathrm{HC}$ vegetable oil into biodiesel under predefined reaction conditions. The high content of unsaturated fatty acids may also explain the conversion rate of vegetable oils at this temperature [32]. 


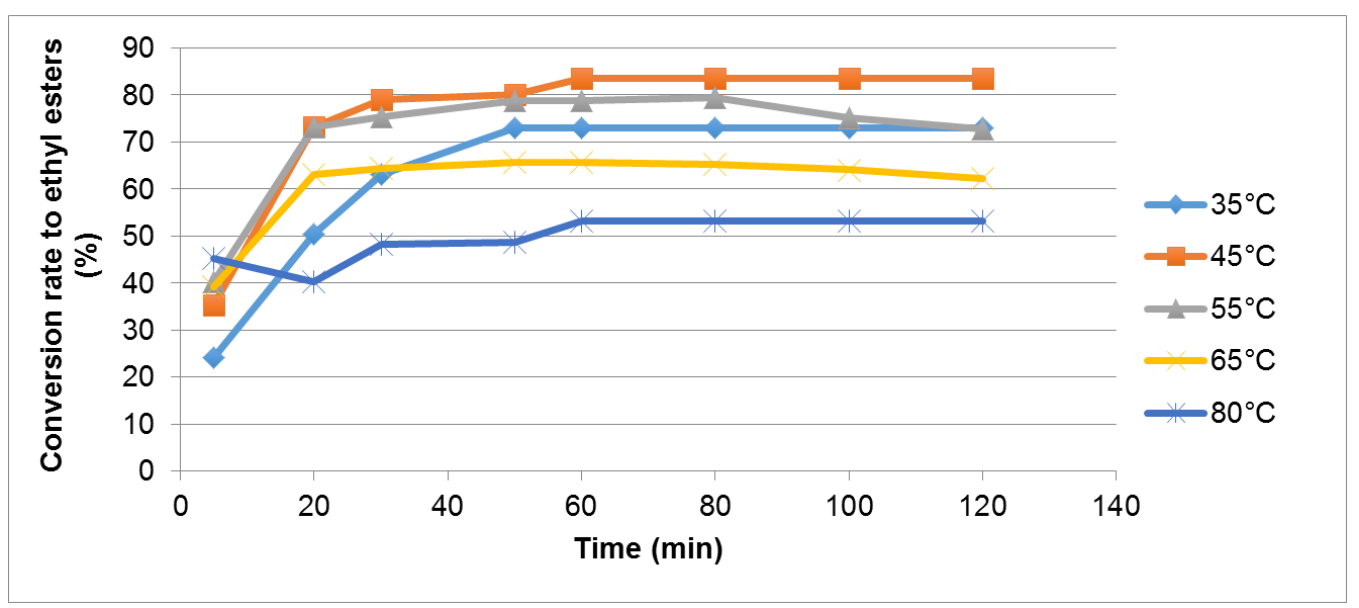

Figure 3. Influence of temperature and reaction time on the conversion rate of Hura crepitans vegetable oil to biodiesel (anhydrous ethanol; ethanol molar ratio: oil of 6; $250 \mathrm{rpm}$ ).

\subsubsection{Effect of Catalyst Concentration and Reaction Time on the Conversion Rate of Vegetable Oils to Biodiesel}

In order to select the amount of catalyst required for the transesterification reaction, a study was conducted and results are presented in Figure 4. From its analysis, it appears that the reaction efficiency is proportional to the catalyst concentration. This is more pronounced at the beginning of the reaction until about $50 \mathrm{~min}$. From $80 \mathrm{~min}$ onwards, the additional addition of potassium hydroxide (KOH) from $1 \%$ to $1.1 \%$ and $1.2 \%(\mathrm{w} / \mathrm{w})$ seems unsuccessful on the yield with vegetable oil of Hura crepitans. It is also noted that $0.9 \% \mathrm{KOH}(\mathrm{w} / \mathrm{w})$ does not offer a good yield. Similarly, $1.2 \% \mathrm{KOH}$ is disadvantageous for the transesterification of vegetable oil from Hura crepitans after $30 \mathrm{~min}$ of reaction. This could be due to a possible competition between the saponification reaction and transesterification [33]. This oil has a good yield after $60 \mathrm{~min}$ reaction with $1.1 \%$ catalyst. In view of these results, the latter grade was therefore used.

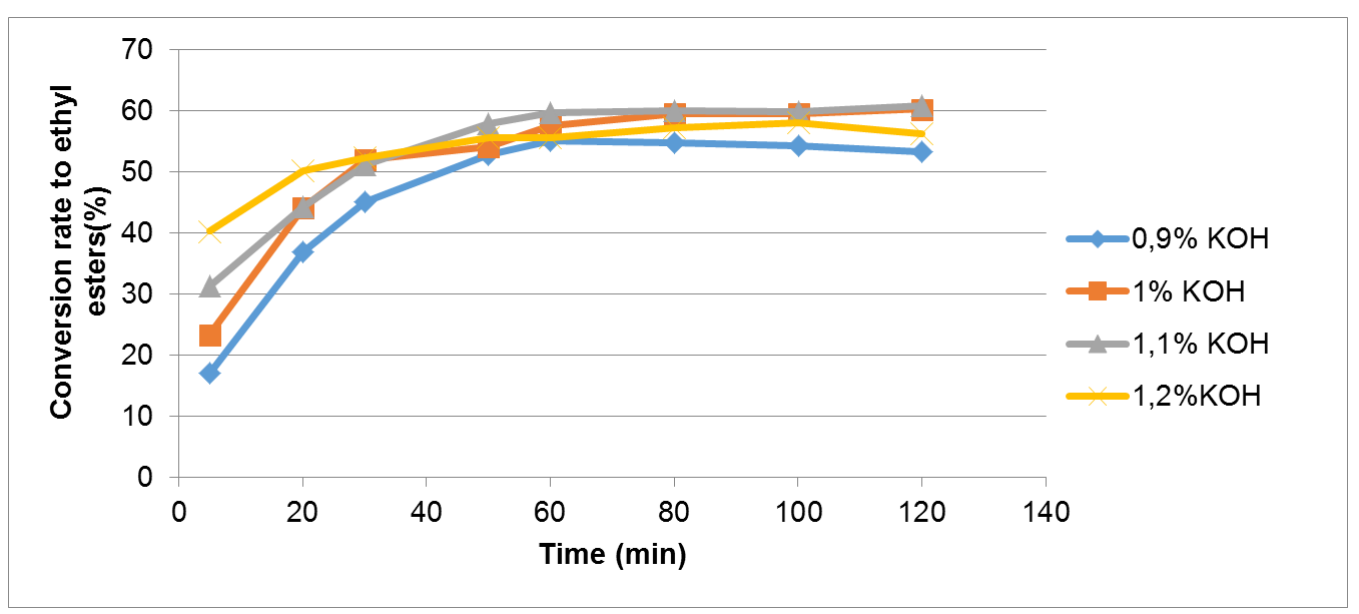

Figure 4. Conversion rate of Hura crepitans vegetable oil for four (04) different concentrations of KOH (anhydrous ethanol; ethanol molar ratio: oil of 6; 250 rpm; $\left.45^{\circ} \mathrm{C}\right)$.

\subsubsection{Ethanolysis of Hura Crepitans Oil Under Optimal Conditions}

The conversion of $\mathrm{HC}$ vegetable oil gave a yield of $81.47 \%$ after one hour of reaction with $1.1 \%$ catalyst and a reaction temperature of $45^{\circ} \mathrm{C}$. It should be noted that settling began 10 to $20 \mathrm{~min}$ after the final product was introduced into the separating funnel. The conversion rate of nonconventional $\mathrm{HC}$ vegetable oil is greater than $80 \%$ obtained by Nitièma-Yefanova et al [34] with Balanites aegytiaca vegetable oil. It should be noticed that Nitièma-Yefanova worked under the following conditions: $35^{\circ} \mathrm{C} ; 1.1 \% \mathrm{KOH}$; an ethanol/oil molar ratio of 6 and a reaction time of $120 \mathrm{~min}$. The same work by this author showed that this yield increased from 80 to $93 \%$ after the addition of glycerol. The latter made it possible to facilitate the separation of the biodiesel-rich organic phase from the aqueous phase; thus an additional production cost. This shows that some of Hura crepitans' Biodiesel would end up in the wash water. The efficiency of the transformation could be improved if we use glycerol for separation and less water for washing with the risk that biodiesel is richer in phospholipids, glycerol, free fatty acids, residual $\mathrm{KOH}$, etc. [35]. 


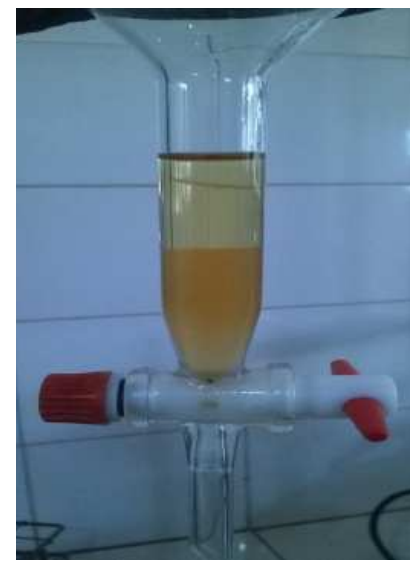

a. Settling of Hura crepitans'biodiesel after washing

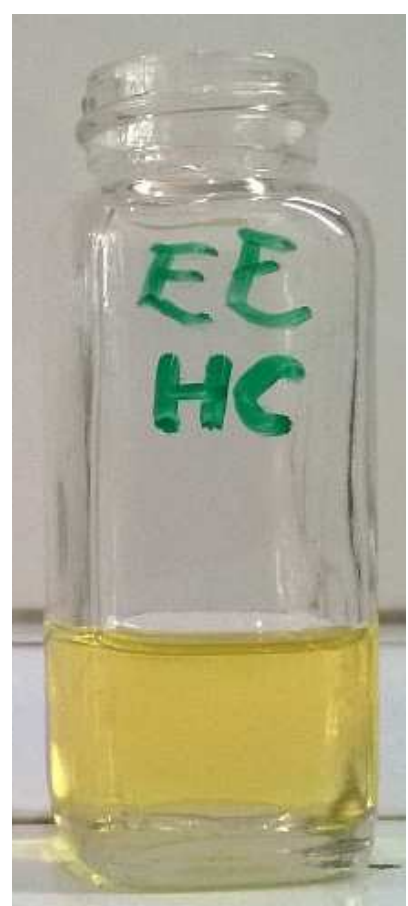

b. Hura crepitans' biodiesel

Figure 5. Separation of Hura crepitans' biodiesel.

\subsection{Some Fuel Characteristics of Biodiesel from Hura Crepitans Vegetable Oil}

The chromatogram in Figure 6a. shows the migration of the stains of the different compounds resulting from the thin layer chromatography of the biodiesel obtained in order to verify its purity. In comparison with Figure $6 \mathrm{~b}$, there is a preponderance of ethyl esters $[18,36]$ as confirmed by the result in Table 3, with an ester yield of $98.48 \%$. The analysis of this table shows a reduction in acidity $(0.41 \%)$, density (0.887) and an increase in the cetane number to 54.44. These values are similar to those of Adewuyi et al. [13] who worked on $\mathrm{HC}$ from Nigeria. All these data, like most of the others in Table 3, comply with biodiesel standards.

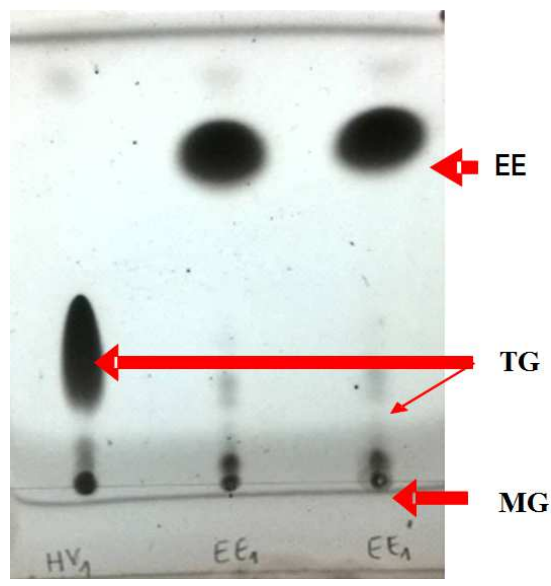

a. Chromatogram of Hura crepitans' biodiesel

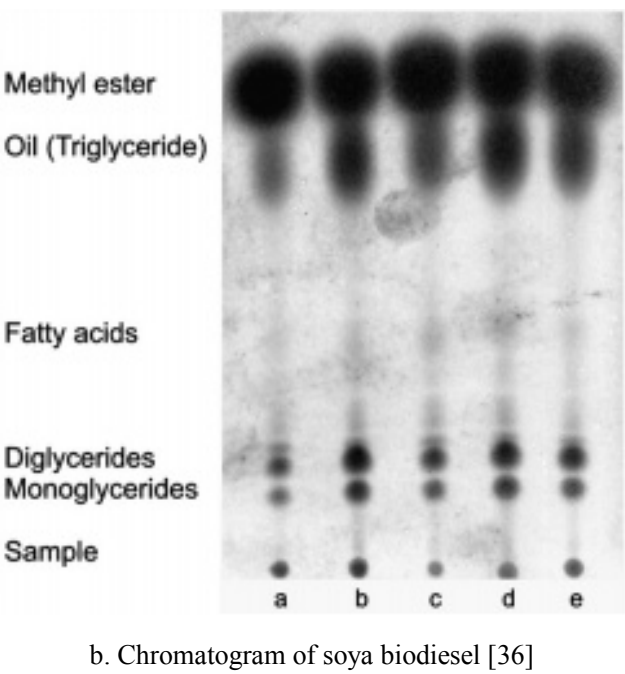

Figure 6. Thin layer chromatography of biodiesels.

Table 3. Some characteristics of Hura crepitans' biodiesel and standards.

\begin{tabular}{lll}
\hline Characteristics & HCB & Biodiesel specification [31] \\
\hline Ethyl ester content (EE, \%) & $98.48 \pm 1.27 \mathrm{a}$ & EN 14214 \\
Triglycerides (TG, \%) & $0.32 \pm 0.02 \mathrm{a}$ & Min: $96.50 \mathrm{a}$ \\
Diglycerides (DG, \%) & $\mathrm{ND}$ & Max: $0.20 \mathrm{a}$ \\
Monoglycerides $(\mathrm{MG}, \%)$ & $0.40 \pm 0.02 \mathrm{~b}$ & Max: 0.20 \\
$\alpha+\gamma-$ ethyl linolenate $(\mathrm{C} 18: 3, \%)$ & $0.30 \pm 0.01 \mathrm{~b}$ & Max: $0.80 \mathrm{a}$ \\
Ethyl timnodonate $(\mathrm{C} 20: 5, \%)$ & $0.02 \pm 0.00 \mathrm{~b}$ & Max: $12 \mathrm{a}$ \\
Moisture content $(\%)$ & $0.03 \pm 0.00 \mathrm{~b}$ & Max: $1 \mathrm{a}$ \\
Acidity $(\%)$ & $0.41 \pm 0.06 \mathrm{a}$ & Max: $0.05 \mathrm{a}$ \\
Density $\left(\right.$ at $\left.26^{\circ} \mathrm{C}\right)$ & $0.887 \pm 0.01 \mathrm{a}$ & Max: $0.50 \mathrm{a}$ \\
Iodine value $\left(\mathrm{g} \mathrm{I}_{2} / 100 \mathrm{~g}\right)$ & $118.03 \pm 1.48 \mathrm{a}$ & $0.86-0.90 \mathrm{a}(*)$ \\
\hline
\end{tabular}




\begin{tabular}{lll}
\hline \multirow{2}{*}{ Characteristics } & HCB & Biodiesel specification [31] \\
\cline { 3 - 3 } & $41.12 \pm 0.07 \mathrm{a}$ & EN 14214 \\
\hline Lower calorific value $(\mathrm{MJ} / \mathrm{kg})$ & $54.44 \pm 2.00 \mathrm{a}$ & Min: 35b \\
Cetane number & $1.471 \pm 0.000$ & Min: $51 \mathrm{a}$ \\
Refractive index & ND \\
\hline
\end{tabular}

HCB: Hura crepitans' biodiesel; ND: Not Detected; $\left({ }^{*}\right)$ : densityat $20^{\circ} \mathrm{C}$.

The data in a line followed by different letters are significantly different $(p<0.05)$. The values are averages of three repetitions \pm standard deviation.

\section{Conclusion}

The kernels of Hura crepitans seeds have a high lipid potential of nearly $52.54 \%$. Vegetable oil is highly unsaturated and deserves protection from air, light and heat. This oil has good physicochemical and energy characteristics, but its direct use in diesel engines is not recommended due to its high acidity and density and lower cetane number as compared to the data provided by the European standard EN 14214. A yield of $81.47 \%$ biodiesel, containing $98.48 \%$ ethyl esters, is obtained in a single step by transesterification of vegetable oil in order to reduce production costs. Among all the treatment variants adopted, it was found that the maximum yield of ethyl esters was obtained using an ethanol/oil molar ratio of 6 and $1,1 \%(\mathrm{~m} / \mathrm{m}) \mathrm{KOH}$ at a reaction temperature of $45^{\circ} \mathrm{C}$. The minimum reaction time required to obtain a maximum ester yield was $60 \mathrm{~min}$. The fuel characteristics of biodiesel are also improved with a reduction in acidity, density and an increase in cetane number. Biodiesel, in view of the results obtained, could be proposed to power Diesel engines without a preheating system.

\section{References}

[1] GIEC. (2014). Changements climatiques 2014: Rapport de synthèse. Contribution des groupes de travail I, II et III au cinquième rapport d'évaluation du Groupe d'experts intergouvernemental sur l'évolution du climat. Genève, Suisse, P. 180.

[2] Ramadhas, A. S., Jayaraj, S. \& Muraleedharan, C. (2005). Biodiesel production from high FFA rubber seed oil. Fuel. 84 (4), 335-340.

[3] Benoist, A. (2009). Eléments d'adaptation de la méthodologie d'analyse de cycle de vie aux carburants végétaux: cas de la première génération. Paris, France, P. 226.

[4] Mellak, A., Le Roux, Y., Bouarab, R. \& Ahmed-Zaïd, T. (2018). Contribution à la production du biogaz à partir d'effluents d'élevage animaliers en Algérie. Algerian Journal of Environmental Science and Technology April edition. 5 (1), 88-889.

[5] Balat, M. \& Balat, H. (2009). Recent trends in global production and utilization of bioethanol fuel. Applied Energy. 86 (11), 2273-2282.

[6] Kulkarni, M. G. \& Dalai, A. K. (2006). Waste cooking oil - an economical source for biodiesel: A review. Industrial \& Engineering Chemistry Research. 45 (9), 2901-2913.
[7] CIRAD. (2008). Guide technique pour une utilisation énergétique des huiles végétales. - Brasilia. Patrick Rousset, Coordonnateur, P. 288.

[8] Khiari, K. (2016). Contribution à l'étude des propriétés thermo-physiques des biocarburants de seconde génération et leur influence sur le comportement des moteurs, Thèse de doctorat de l’Université Bretagne Loire, 195p.

[9] Subhedar, P. B. \& Gogate, P. R. (2016). Ultrasound assisted intensification of biodiesel production using enzymatic interesterification. Ultrasonics Sonochemistry. 29, 67-75.

[10] Richard, R., Li, Y., Dubreuil, B., Thiebaud-Roux, S. \& Prat, L. (2011). On-line monitoring of the transesterification reaction between triglycerides and ethanol using near infrared spectroscopy combined with gas chromatography. Bioresource Technology. 102 (12), 6702-6709.

[11] Nitièma-Yefanova, S. (2013). Optimisation de la production $\mathrm{du}$ biodiesel éthylique à partir des huiles végétales non conventionnelles. Thèse de doctorat à l'Université de Ouagadougou (Burkina Faso), 219p.

[12] Demirbas, F. M., Balat, M. \& Balat, H. (2011). Biowastes-tobiofuels. Energy Conversion and Management. 52 (4), 18151828 .

[13] Adewuyi, A., Awolade, P. O. \& Oderinde, R. A. (2014). Hura crepitans Seed Oil: An Alternative Feedstock for Biodiesel Production. Journal of fuels, P. 8.

[14] Babatunde, O. A. \& Bello, G. S. (2016). Comparative assessment of some Physicochemical Properties of Groundnut and Palm Oils Sold Within Kaduna Metropolis, Nigeria. IOSR Journal of Applied Chemistry. 9 (11), 2278-5736.

[15] Ackman, R. G. (1998). Laboratory preparation of conjugated linoleic acids. Journal of The American Oil Chemists' Society. 75, 541-545.

[16] Lepage, G. \& Roy, C. C. (1986). Direct transesterification of all classes of lipids in a one-step reaction. Journal of Lipid Research. 27, 114-120.

[17] Masood, A., Stark, K. D. \& Salem Jr, N. (2005). A simplified and efficient method for the analysis of fatty acid methyl esters suitable for large clinical studies. Journal of Lipid Research. 46, 2299-2305.

[18] Ichihara, K. \& Fukubayashi, Y. (2010). Preparation of fatty acid methyl esters for gas-liquid chromatography. Journal of Lipid Research. 51, 635-640.

[19] Issariyakul, T., Kulkarni, M. G., Meher, L. C., Dalai, A. K. \& Bakhshi, N. N. (2008). Biodiesel production from mixtures of canola oil and used cooking oil. Chemical Engineering Journal. 140, 77-85.

[20] Omeje, K. O., Iroha, O. K., Edeke, A. A., Omeje, H. C. \& Apeh, V. O. (2019). Characterization and fatty acid profile analysis of oil extracted from unexploited seed of African star apple (Udara). OCL, 26 (10), 1-5. 
[21] Gharby, S., Harhar, H., Bouzoubaa, Z., Roudani, A., Chafchaouni, I., Kartah, B. \& Charrouf, Z. (2014). Effet des Polyphénols extraits des margines sur la stabilité de l'huile de tournesol (Effect of Polyphenols extracts from margins on the stability of sunflower oil). J. Mater. Environ. Sci. 5 (2), 464469 .

[22] Pouyet, B. \& Ollivier, V. (2014). Réglementations sur l'étiquetage et la présentation des huiles d'olive. OCL, 21 (5), $1-7$.

[23] Ozcan, M. M., Gumuscu, A. F. Er., Arslan, D. \& Ozkalp, B. (2010). Chemical and fatty acid composition of Cyperus esculentus. Chemistry of Natural Compounds. 46, 276-277.

[24] Yeboah, S. O., Mitei, Y. C., Ngila, J. C., Wessjohann, L. \& Schmidt, J. (2012). Compositional and structural studies of the oils from two edible seeds: Tiger nut, Cyperus esculentum and asiato, Pachira insignis, from Ghana. Food Research International. 47, 259-266.

[25] Owolabi, J. B., Alabi, K. A. \& Lajide, L. (2015). Synthesis and characterization of copper metal soaps from Thevetia peruviana and Hura crepitans seed oils. Scientific research and Essays. 10 (23), 649-654.

[26] Di Vaio, C., Nocerino, S., Paduano, A. \& Sacchi, R. (2012). Influence of some environmental factors on drupe maturation and olive oil composition. Journal of the Science of Food and Agriculture, 93 (5), 1134-1139.

[27] Redondo-Cuevas, L., Castellano, G., Torrens, F. \& Raikos, V. (2018). Revealing the relationship between vegetable oil composition and oxidative stability: A multifactorial approach. Journal of Food Composition and Analysis, 66, 221-229.

[28] Umoren, S. A., Ajibersin, K. K. \& Bala, D. N. (2001). Physico-chemical properties of the seed and seed oil of Hura crepitans. Journal of Natural and Applied Sciences. 1 (2), 2326.
[29] Oyekunle, J. A. O. \& Omode, A. A. (2008). Chemical composition and fatty acid profile ofthe lipid fractions of selected Nigerian indigenous oil seeds. International Journal of Food Properties. 11, 273-281.

[30] Ezeh, I. E., Umoren, S. A., Essien, E. E. \& Udoh, A. P. (2012). Studies on the utilization of Hura crepitans L. seed oil in the preparation of alkydresins. Industrial Crops and Products. 36, 94-99.

[31] CIRAD. (2014). Technical guide for the use of vegetable fuel in stationary engines. Harmattan Burkina, P. 111.

[32] Richard, R. (2011). Transestérification éthanolique d'huile végétale dans des microréacteurs: transposition du batch au continu. Thèse de doctorat: Université de Toulouse (France).

[33] Mengata Mengounou, G. (2017). Elaboration et caractérisation d'un liquide isolant naturel à base d'huile de palmistes conditionnée, Thèse de doctoratde l'Université de Douala.

[34] Nitièma-Yefanova, S., Coniglio, L., Schneider, R., Nébié, R. H. C. \& Bonzi-Coulibaly, Y. L. (2016). Ethyl biodiesel production from non-edible oils of Balanites aegyptiaca, Azadirachta indica, and Jatropha curcas seeds - Laboratory scale development. Renewable Energy. 96 (Part A), 881-890.

[35] Lu, H., Liu, Y., Zhou, H., Yang, Y., Chen, M. \& Liang, B. (2009). Production of biodiesel from Jatropha curcas L. oil. Computers and Chemical Engineering. 33, 1091-1096.

[36] Santos, F. F. P., Rodrigues, S. \& Fernandes, F. A. N. (2009). Optimization of the production of biodiesel from soybean oil by ultrasound assisted methanolysis. Fuel processing technology. 90, 312-316. 